\title{
Author Correction: Dynamic fibroblast contractions attract remote macrophages in fibrillar collagen matrix
}

Pardis Pakshir,2,3, Moien Alizadehgiashi ${ }^{4}$, Boaz Wong ${ }^{5}{ }^{5}$, Nuno Miranda Coelho ${ }^{2}$, Xingyu Chen ${ }^{6}$, Ze Gong ${ }^{6}$, Vivek B. Shenoy ${ }^{6}$, Christopher A. McCulloch (1) ${ }^{2}$ \& Boris Hinz (1) 1,2,3

Correction to: Nature Communications https://doi.org/10.1038/s41467-019-09709-6, published online 23 April 2019.

The original version of this Article contained an error in the spelling of the author Christopher A. McCulloch, which was incorrectly given as Christopher McCulloch. This has now been corrected in both the PDF and HTML versions of the Article.

Published online: 20 May 2019

\begin{abstract}
(c) (i) Open Access This article is licensed under a Creative Commons Attribution 4.0 International License, which permits use, sharing, adaptation, distribution and reproduction in any medium or format, as long as you give appropriate credit to the original author(s) and the source, provide a link to the Creative Commons license, and indicate if changes were made. The images or other third party material in this article are included in the article's Creative Commons license, unless indicated otherwise in a credit line to the material. If material is not included in the article's Creative Commons license and your intended use is not permitted by statutory regulation or exceeds the permitted use, you will need to obtain permission directly from the copyright holder. To view a copy of this license, visit http://creativecommons.org/licenses/by/4.0/.
\end{abstract}

(c) The Author(s) 2019

\footnotetext{
${ }^{1}$ Laboratory of Tissue Repair and Regeneration, Faculty of Dentistry, University of Toronto, Toronto, ON M5G 1G6, Canada. ${ }^{2}$ Faculty of Dentistry, University of Toronto, Toronto, ON M5G 1G6, Canada. ${ }^{3}$ Institute of Biomaterials and Biomedical Engineering, University of Toronto, Toronto, ON M5S 3G9, Canada. ${ }^{4}$ Department of Chemistry, University of Toronto, Toronto, ON M5S 3E5, Canada. ${ }^{5}$ Department of Physiology, University of Western Ontario, London, ON, Canada. ${ }^{6}$ Center for Engineering Mechanobiology and Department of Materials Science and Engineering, School of Engineering and Applied Science,

University of Pennsylvania, Philadelphia, PA 19104, USA. Correspondence and requests for materials should be addressed to B.H. (email: boris.hinz@utoronto. ca)
} 